\title{
Desalination and Characterization of Salty Soils from Upper Myanmar
}

\author{
Win Ei Ei Tun \\ Chemical Engineering \\ Ministry of Education \\ Thanlyin, Myanmar
}

\author{
Ei Mon Khin \\ Chemical Engineering \\ Yangon, Myanmar
}

\author{
Si Si Win \\ Chemical Engineering \\ Visiting Lecturer \\ Yangon, Myanmar
}

\begin{abstract}
A preliminary study is made to manage the reclamation of salt-affected soil sample from Oak Twin Village, Nahtogyi Township, Mandalay Division in Upper Myanmar. The three layers $\left(0-0.5^{\prime}, 0.5-1^{\prime}, 1-1.5^{\prime}\right)$ of salty soil samples are collected after the end of rainfall season (October) and stored with moisture tightness plastic bags. Characterization and classification of soil types are done before the soil remediation. From observing the analyzed data, the soil is classified as saline-alkaline type. The initial $\mathrm{pH}$ values for the three layers are found to be 10.6, 10.4 and 10.3 respectively. The original properties of soil sample are also examined in this experiment and the second layer $\left(0.5^{\prime}-1.0^{\prime}\right)$ is the highest value, $9.478 \mathrm{dS} / \mathrm{m}$ in the salinity profile $\mathrm{EC}_{\mathrm{e}}$ (Electrical Conductivity). The amelioration measures for saline-alkaline are required two approaches, the replacement of exchangeable sodium by calcium from gypsum treatments and removal of displaced sodium by leaching. The experimental design is set up as Randomized Complete Block Design (RCBD) with 4 treatments and 4 replications using 16 flower-pots is done with the three layers soil. The results showed that ESP (Exchangeable Sodium Percentage), $\mathrm{EC}_{\mathrm{e}}, \mathrm{pH}$ values of 3 layers are decreased to a certain level (ie. salinity is reduced) after 4 weeks intervals. Reduction efficiency for the conditioned soil of the surface soil layer in this work, reveals that $12.03 \%$ for soil $\mathrm{pH}$, $68.59 \%$ for $\mathrm{EC}_{\mathrm{e}}$ and $60.29 \%$ for ESP. This method is economically feasible for the soil management. Rice plant growth is tested on the gypsum treated soil and it can be seen that the germination is quite well, whereas no germination is occurred in salt-affected soils. From these results it can be drawn that salinity effects on rice crops of growth and yield in this selected area is negligible after using with this approach.
\end{abstract}

Keywords: salty soils, Electrical Conductivity, Exchangeable Sodium Percentage, Randomized Complete Block Design

\section{INTRODUCTION}

Soil salinization and water logging are major problems affecting agricultural production in the world. Food and Agricultural Organization (FAO) estimated that salinization affects about 20 to 30 million hectares of the world's irrigated land [1]. This means that nearly ten percent of the total land area in the world is affected by soil salinization.

In the Asia and Pacific region, saline/sodic soils are formed by salinization and alkalization processes that drastically reduce the land's capacity to achieve potential yields and may lead to complete crop failure. The extent of such salt affected land is on the increase, thus FAO was organized to facilitate the exchange of experience on the reclamation and management of saline/sodic soils [1].

Salinization is the accumulation of soluble salts of sodium, magnesium and calcium in soils. These salts can affect soils to the extent that crop production is severely limited. High levels of soil salinity limit plant growth; the increased osmotic pressure of soil solution reduces the plant's capacity to withdraw water from the soil. The increasing human population of the world makes it necessary for the earth's soil resources to be maintained in order to meet the increasing demand for food. Every continent contains areas with saltaffected soils and at least seventy-five countries worldwide have serious salinization problems [2]. The major factor in the development of saline soils is a lack of precipitation. Most naturally saline soils are found in (semi) arid region and climates of the globe [3].

Many saline regions of the world occur naturally. Saline regions are found in poorly drained low-lying areas within semi-arid and arid climates in which large qualities of salts have leached from regions of higher elevation. These leached salts accumulate in the slow flowing ground water and are brought to the soil surface, in these low-lying areas, through high evapotranspiration rate [4].

Gypsum $\left(\mathrm{CaSO}_{4} \cdot 2 \mathrm{H}_{2} \mathrm{O}\right)$ has a long history of use as agricultural amendment; in highly weathered soils, it provides the plant nutrients calcium $\left(\mathrm{Ca}^{2+}\right)$ and sulfate $\left(\mathrm{SO}_{4}{ }^{2-}\right)$ and improves plant growth through ameliorating deficiencies of these plant nutrients. Salt-affected soils that are not severely saline-sodic and are under irrigation may benefit the most from gypsum application [5].

Soil leaching is believed to be the only practical way to reduce excessive soluble salts from soils. It can be achieved by applying low-salinity water to soil. The water percolates through the active root zone depth of the soil carrying away salts. Leaching requires installation of a subsurface drainage system if no natural drainage pathway is present and is limited by land topography and soil characteristics. Leaching of clay soils can be difficult since most drainage in cracking clay soils travels through micropores and does not interact with the soil matrix. During leaching, salt contained in the water within the micropores may be considered to be immobile and cannot be removed from the soil profile [6].

Despite the apparent simplicity of the soil leaching method, it requires through investigations on soil and water characteristics to determine the optimum depth of leaching water. Soil leaching can be expensive and time consuming. Furthermore, soil leaching necessitates the availability of high quality irrigation water for leaching which can be a limiting factor in arid and semi-arid lands [7].

In this study, chemical amendment using gypsum treatment followed by leaching is carried out for salt removal.

This work aims to choose a desalination method (relatively inexpensive and easy to perform) and to characterize the saltaffected soil and desalinized soil. The objectives are to 
explore the amount of gypsum requirement of soil, to maintain an acceptable crop yield and to enable the management of salt-affected soil.

\section{MATERIALS}

\subsection{Raw Material}

Salt contaminated soil (problem areas soil from Oak Twin Village, Nahtogyi township of Mandalay Division) is used to study for the remediation process.

\section{METHOD}

\subsection{Selection of Soil for Remediation}

Salt affected area, Oak Twin Village, Nahtogyi township of Mandalay Division (Figure 1 and 2) is selected in this experiment.

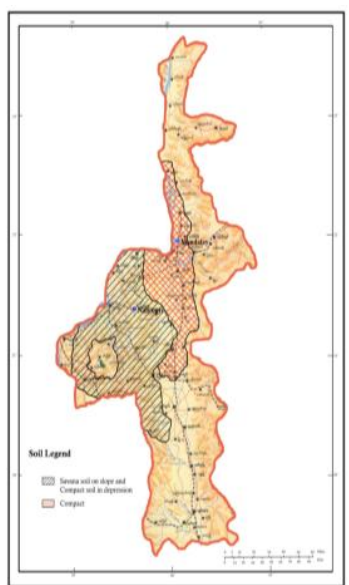

Figure 1. Soil Map of Mandalay Division

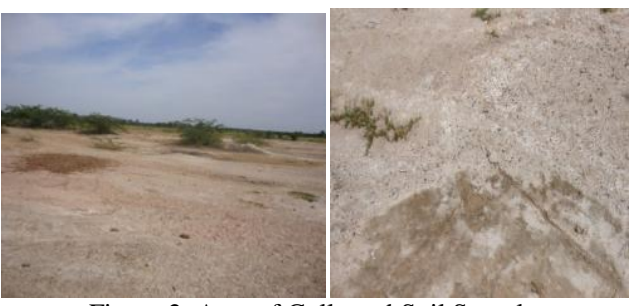

Figure 2. Area of Collected Soil Sample

\subsection{Sampling and Collection of Soil}

Soil samples from the depth of 0 to $0.5^{\prime}, 0.5^{\prime}$ to $1^{\prime}$ and $1^{\prime}$ to $1.5^{\prime}$ (3 layers) are kept separately in each bags of double packing style with wooven bag and plastic bag to maintain moisture tightness. All samples are properly labeled. The samples are transported to the laboratory for analysis as soon as practical to prevent any chemical changes occurring. Soil samples are collected after the end of the rainfall season (October).

\subsection{Classification of Soil Types}

The soil samples of each layer are classified for the soil types by Myanma Agriculture Service (Land Use), Ministry of Agriculture and Irrigation, Union of Myanmar. Texture, $\mathrm{pH}$, EC, ESP and CEC of the soil samples are analyzed for separating soil types.

\subsection{Characterization of Soil Sample}

The characteristics (moisture and soluble salts such as $\mathrm{Ca}$, $\mathrm{Mg}, \mathrm{Fe}, \mathrm{Na}, \mathrm{Mn}, \mathrm{S}, \mathrm{K}, \mathrm{Pb}, \mathrm{P}, \mathrm{Cu}, \mathrm{Zn}$ ) of the three soil layers are also analyzed for this work.

\subsection{Determination of Soil Salinity}

Soil salinity $\left(\mathrm{pH}, \mathrm{EC}_{\mathrm{e}}\right.$ and $\left.\mathrm{ESP}\right)$ of soil samples is determined according the procedures of Myanma Agriculture Service (Land Use).

\subsection{Soil Amendment (Management) Process} 3.6.1. Determination of Gypsum Content in the Soil Sample and Local Gypsum Purity

The amount of gypsum contained in the soil sample and the purity percent of local gypsum are determined.

\subsubsection{Leaching Water Analysis}

In this work, fresh water ( tap water) is used for leaching purpose in the 16 flower pots. Thus, the soluble salts containing water are determined and the resulting data are given in Table 4.4

\subsubsection{Experimental Set up Design}

The four flower pots are marked as A, B, C and D. Then, a randomized block design was set up using $(4 \times 4)$ flower-pots (size $\left.\sim 1.5^{\prime} \times 8.5^{\prime}\right)$, each pot with one layer of soil depth 0 $0.5^{\prime}, 0.5-1^{\prime}$ are placed into pot $\mathrm{A}$ and $\mathrm{B}$. In the pot $\mathrm{C}$ and $\mathrm{D}$, the above mixed 3 layers are put into it as shown in experimental set up design and Pot D is marked as control with no gypsum, only leaching is made. The calculated amout of gypsum for each layer $(13.74 \mathrm{~g}, 11.77 \mathrm{~g}$, and $31.428 \mathrm{~g}$ ) are applied into the pots (A, B and C) and leaching water is maintained above the soil surface of $3 \mathrm{~cm}$ during the 4 weeks treatment. The 16 pots are arranged at random and experimental layout is mentioned.
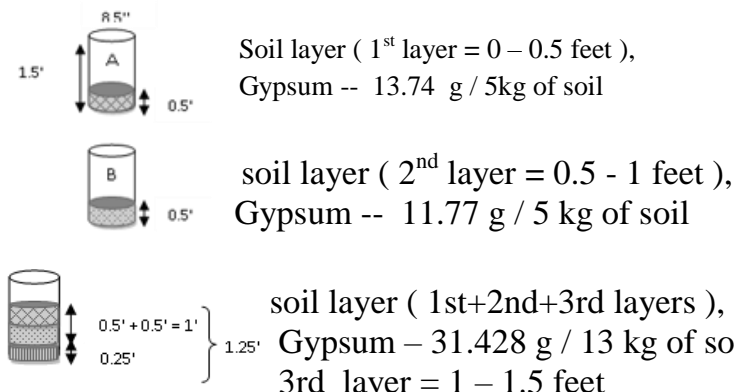

soil layer ( 1 st $+2 \mathrm{nd}+3$ rd layers $)$,

5. Gypsum $-31.428 \mathrm{~g} / 13 \mathrm{~kg}$ of soil 3rd layer $=1-1.5$ feet

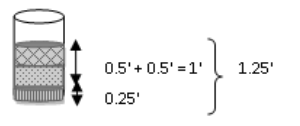
soil layer $\left(1^{\text {st }}+2^{\text {nd }}+3^{\text {rd }}\right.$ layers $)$ (control) (No gypsum, only leaching)

$$
\begin{aligned}
& \text { Flower pot size } \quad=\mathrm{h} \times \mathrm{d}=1.5^{\prime} \times 8.5^{\prime \prime} \\
& \text { Soil layer weight }=5 \mathrm{~kg} \text { of } 1^{\text {st }} \text { layer in Pot A } \\
& =5 \mathrm{~kg} \text { of } 2^{\text {nd }} \text { layer in Pot } \mathrm{B} \\
& =5 \mathrm{~kg} \text { of } 1^{\text {st }} \text { layer }+5 \mathrm{~kg} \text { of } 2^{\text {nd }} \text { layer } \\
& +3 \mathrm{~kg} \text { of } 3^{\text {rd }} \text { layer in Pot C } \\
& =5 \mathrm{~kg} \text { of } 1^{\text {st }} \text { layer }+5 \mathrm{~kg} \text { of } 2^{\text {nd }} \text { layer } \\
& +3 \mathrm{~kg} \text { of } 3^{\text {rd }} \text { layer in Pot D }
\end{aligned}
$$




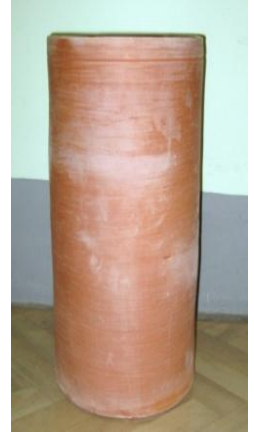

\begin{tabular}{|c|c|c|c|}
\hline $\mathrm{C}$ & $\mathrm{A}$ & $\mathrm{B}$ & $\mathrm{D}$ \\
\hline $\mathrm{A}$ & $\mathrm{D}$ & $\mathrm{B}$ & $\mathrm{C}$ \\
\hline $\mathrm{D}$ & $\mathrm{B}$ & $\mathrm{C}$ & $\mathrm{A}$ \\
\hline $\mathrm{A}$ & $\mathrm{C}$ & $\mathrm{D}$ & $\mathrm{B}$ \\
\hline
\end{tabular}

Figure 3. The Sample of Flower Pot and Randomization Procedure Design

where as ,

$\mathrm{A}=$ Soil for $1^{\text {st }}$ layer (with gypsum and leaching)

$\mathrm{B}=$ Soil for $2^{\text {nd }}$ layer (with gypsum and leaching)

$\mathrm{C}=$ Soil for mixed layer (with gypsum and leaching)

$\mathrm{D}=$ Soil for mixed layer (control) (no gypsum, only leaching)

Soil remediation steps are carried out as follow (Figure 4):

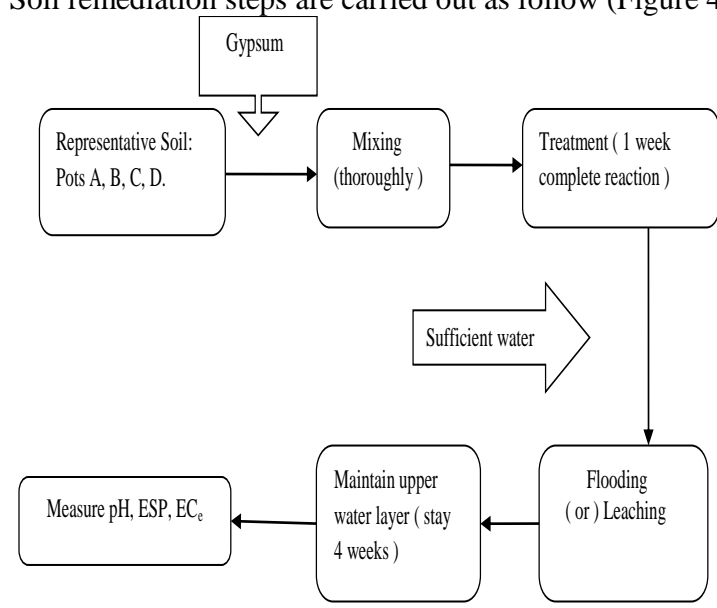

Figure 4. Procedure for Soil Remediation

\subsubsection{Determination of gypsum requirement}

The requirement of gypsum for the treatment of soil samples is determined.

\subsection{Determination of the Characteristics of the Gypsum Treated Soil}

The treated soil samples from the 16 flower pots (A, B, C, D) are taken out at weekly intervals and the $\mathrm{pH}$ values, $\mathrm{EC}_{\mathrm{e}}$ values and ESP values are determined.

\subsection{Testing of the Gypsum Treated Soil for Plant Growth}

The paddy grains are spread out into the treated soil and untreated (original) soil containing flower pots and examined for the growth, as shown in Figure 4.

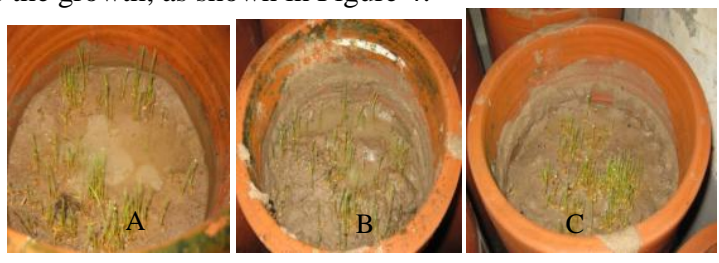

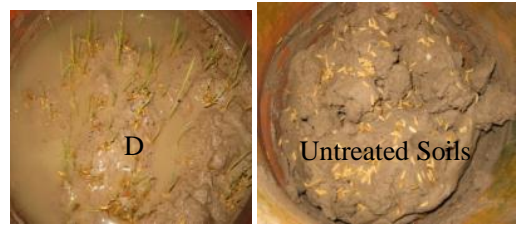

Figure 4. ( a ) Testing of Rice Plant Growth in the Gypsum Treated Soil and Untreated Soil (5 days)
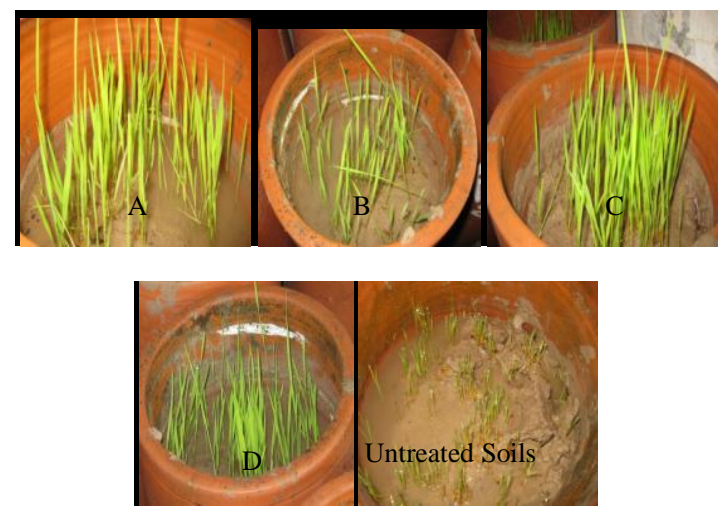

Figure 4.( b ) Testing of Rice Plant Growth in the Gypsum Treated Soil and Untreated Soil (18 days)

\section{RESULTS AND DISCUSSION}

\subsection{Observation of Salt-affected Soil Area and Soil Sampling}

Clues concerning soil salinity in this work are studied, when observing (looking) at a field (as shown in Figure. 3.5.) carefully reveal:

(1) Cracking ( a clear sign of clay/silt sediments )

(2) Salt accumulation (can see visible on the surface indicates shortage of rainfall )

(3) Vegetation (obviously a good sign of recovery)

From these observations, if there is neither clay/silt sediment nor vegetation, it may mean that saline water is trapped below the surface and is hindering plant establishment (called waterlogging).

Soil depths in remediation processes vary according to ground water depth, soil type and plant application after remediation. Generally, root zone factors indicate soil depth as being $1.5 \mathrm{ft}$ using plant root area as the necessary determining factor coupled with desalinization prevention. The sampling spot (soil layer) located in the middle of the land area. The surface of the soil that is top layer (up to $0.5 \mathrm{ft}$ ) is dug and taken into woven-plastic bag. The second layer (up to $1.0 \mathrm{ft}$ ) and the third layer (up to $1.5 \mathrm{ft}$ ) are also dug and taken into each separate bag. The soil samples are stored in double packed for further studies.

\subsection{Soil Classification and Soil Characterizations}

The collected sample of the three layers are classified and characterized for evaluation the performance of soil remediation techniques in the present study. Tables 4.1 and 4.2 (a) display the soil type and its characterize before remediation process. The $\mathrm{pH}$ levels of the $1: 2.5$ solutions are seen in the alkaline conditions (10.6, 10.4 and 10.3) which indicate that there are some soluble salts in the soil. Both $\mathrm{pH}$ and alkalinity can classify the soil in the saline-alkaline category. The analyzed data of minerals and trace elements are also represented in Table 4.2 ( b ). 
Table 4.1. Classification of Soil Type

\begin{tabular}{|c|c|c|c|c|c|}
\hline $\begin{array}{c}\text { Depth } \\
\text { in feet }\end{array}$ & $\begin{array}{c}\mathrm{pH} \\
(1: 2.5) \\
(\text { soil }: \\
\text { water })\end{array}$ & $\begin{array}{c}\text { Sand } \\
\%\end{array}$ & Silt \% & $\begin{array}{c}\text { Cla } \\
\mathrm{y} \%\end{array}$ & Texture \\
\hline $\begin{array}{c}1^{\text {st }} \\
\text { layer } \\
(0-0.5)\end{array}$ & 10.6 & 85 & 4.7 & 8 & Loamy sand \\
\hline $\begin{array}{c}2^{\text {nd }} \\
\text { layer } \\
(0.5-1)\end{array}$ & 10.4 & 58 & 16.8 & 24 & $\begin{array}{c}\text { Sandy clay } \\
\text { loam }\end{array}$ \\
\hline $\begin{array}{c}3^{\text {rd }} \\
\text { layer } \\
(1-1.5)\end{array}$ & 10.3 & 52.5 & 23.7 & 21 & $\begin{array}{c}\text { Sandy clay } \\
\text { loam }\end{array}$ \\
\hline
\end{tabular}

Laboratory: Myanma Agriculture Service (Land Use)

Table 4.2.( a ) Analysis of Soil Sample

\begin{tabular}{|c|c|c|}
\hline $\begin{array}{c}\text { Characteristic of soil } \\
(\%)\end{array}$ & $\begin{array}{c}1^{\text {st }} \text { layer } \\
(0-0.5 \text { feet })\end{array}$ & $\begin{array}{c}2^{\text {nd }} \text { layer } \\
(0.5-1 \text { feet })\end{array}$ \\
\hline Iron $\left(\right.$ as $\left.\mathrm{Fe}_{2} \mathrm{O}_{3}\right)$ & 3.57 & 4.28 \\
\hline Aluminium $\left(\right.$ as $\left.\mathrm{Al}_{2} \mathrm{O}_{3}\right)$ & 4.33 & 4.50 \\
\hline Calcium $($ as $\mathrm{CaO})$ & 7.29 & 15.11 \\
\hline Magnesium $($ as $\mathrm{MgO})$ & 0.81 & 2.03 \\
\hline Nitrogen $($ as $\mathrm{N})$ & 0.07 & 0.03 \\
\hline Sulphur $\left(\right.$ as $\left.\mathrm{SO}_{4}\right)$ & 0.09 & 0.04 \\
\hline Chlorine $($ as $\mathrm{Cl})$ & 0.008 & 0.02 \\
\hline Carbonate $\left(\right.$ as $\left.\mathrm{CaCO}_{3}\right)$ & 0.05 & 0.09 \\
\hline Bicarbonate $\left(\right.$ as $\left.\mathrm{HCO}_{3}\right)$ & 0.06 & 0.01 \\
\hline Potassium ( as $\left.\mathrm{K}_{2} \mathrm{O}\right)$ & 0.88 & 1 \\
\hline Phosphorous $\left(\right.$ as $\left.\mathrm{P}_{2} \mathrm{O}_{5}\right)$ & $<0.002$ & 0.05 \\
\hline
\end{tabular}

Laboratory: Analysis Department, MSTRD

Table 4.2.(b) Elemental Analysis

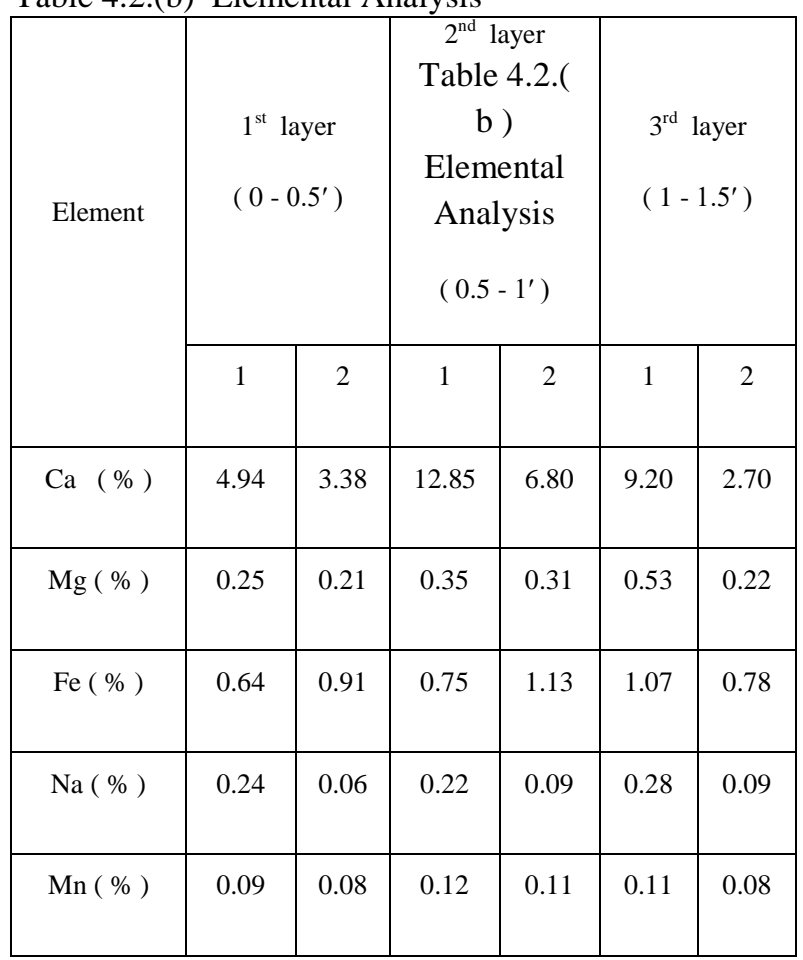

\begin{tabular}{|c|c|c|c|c|c|c|}
\hline S ( \% ) & 2.24 & 0.32 & 1.28 & 0.64 & 0.96 & 0.32 \\
\hline $\mathrm{K}(\mathrm{ppm})$ & 360 & 410 & 430 & 420 & 580 & 440 \\
\hline $\mathrm{Pb}(\mathrm{ppm})$ & 135 & 0 & 109 & 57 & 123 & 0 \\
\hline $\mathrm{P}(\mathrm{ppm})$ & 50 & 0.01 & 60 & 0.01 & 60 & $\begin{array}{c}0.00 \\
2\end{array}$ \\
\hline $\mathrm{Cu}(\mathrm{ppm})$ & 10 & 0 & 14 & 0 & 14 & 0 \\
\hline $\mathrm{Zn}(\mathrm{ppm})$ & 7 & 38 & 14 & 38 & 14 & 33 \\
\hline Mo (ppm) & 0 & 0 & 0 & 0 & 0 & 0 \\
\hline
\end{tabular}

$1=$ Original Soil, $2=$ Treated Soil

Laboratory: Department of Geological Survey and Mineral Exploration Chemical Laboratory

Elements in the original soil and gypsum treated soil are analysed by AAS method results obtained are presented in Table 4.2(b). Macronutrients such as N, P, K, Ca, Mg, S and micronutrients (trace levels) such as $\mathrm{Cl}, \mathrm{Fe}, \mathrm{Mn}, \mathrm{Na}, \mathrm{Zn}, \mathrm{Cu}$ are contained in the original soil sample. Although there are responsible cations $(\mathrm{Ca}, \mathrm{Mg}, \mathrm{K}$ and $\mathrm{Na}$ ) for exchangeable cation in the original soil, the $\mathrm{Na}^{+}$ions are not in excessive amount $(\sim 0.24 \%)$.

The decrease in amount of cations, shown in Table 4.2(b), means that after the treatment process, some salts come out and solubilize in leaching water. Sulphur content in the $1^{\text {st }}$ layer is $2.24 \%$ which is excessive ( i.e > $0.01 \%$ ) amount reduced to $0.32 \%$ after the treatment. The level of $\mathrm{K}$ and $\mathrm{Zn}$ ions in soil increased to some extent after reclamation. This may be due to the contaminants from possible source such as stirring iron rod and shovel, used in this experiment and some $\mathrm{K}^{+}$ions of leaching water deposited on soil during evapotranspiration process. Owing to the difference of moisture content in soil, the comparison values of calculated reduction efficiency can only be interpreted as estimation (approximation).

From the above table, $\mathrm{Na}, \mathrm{Ca}, \mathrm{Mg}, \mathrm{Fe}, \mathrm{Mn}$ and $\mathrm{S}$ contents of original soil are in high values and indicated as salt-affected soil. $\mathrm{S}$ is required by crops in amounts comparable with $\mathrm{P}$. The normal total $\mathrm{S}$ concentration in vegetable tissue is 0.12 $0.35 \%$ and the total $\mathrm{S}$ ratio is about 15 . Plant roots absorb $\mathrm{S}$ primarily as the sulphate ion $\left(\mathrm{SO}_{4}{ }^{\circ}\right)$ [20]. In the soil sample $\mathrm{S}$ as $\mathrm{SO}_{4}{ }^{=}$contains $0.09 \%$ ( in Table 4.2(a) ) whereas the total $\mathrm{S}$ concentration is $0.32 \%$ in treated condition ( in Table 4.2(b) ). It does not appear $\mathrm{S}$ toxicity in plants at that sulfur level. But, S-toxicity symptoms can appear as necrotic spots on leaves, which then spread over the whole leaf at high levels of atmospheric $\mathrm{SO}_{2}$.

\subsection{Soil Analysis}

The original (initial) properties of soil extract before the treatment is analyzed and the data obtained is given in Table 4.3 . 
Table 4.3. The Original Properties of Soil Sample

\begin{tabular}{|c|c|c|c|}
\hline Characteristics & $\begin{array}{c}1^{\text {st }} \text { layer } \\
(0-0.5 \\
\text { feet })\end{array}$ & $\begin{array}{c}2^{\text {nd }} \text { layer } \\
(0.5-1 \\
\text { feet })\end{array}$ & $\begin{array}{c}3^{\text {rd }} \text { layer } \\
(1-1.5 \\
\text { feet })\end{array}$ \\
\hline Moisture ( \%) & 0.62 & 1.43 & 1.23 \\
\hline $\mathrm{pH}$ & 10.62 & 10.4 & 10.43 \\
\hline $\mathrm{EC}_{\mathrm{e}}(\mathrm{mS} / \mathrm{cm})$ & 8.1856 & 9.4789 & 4.6784 \\
\hline $\begin{array}{c}\text { CEC } \\
(\mathrm{Meq} / 100 \mathrm{gm}) \\
\end{array}$ & 30.287 & 34.215 & 32.22 \\
\hline SAR & 14.424 & 27.622 & 6.903 \\
\hline $\begin{array}{c}\mathrm{Ex} ; \mathrm{Na} \\
(\mathrm{Meq} / 100 \mathrm{gm})\end{array}$ & 21.49 & 21.73 & 21.25 \\
\hline ESP & 35.7034 & 38.3936 & 41.9254 \\
\hline $\begin{array}{c}\text { Organic Carbon } \\
(\%)\end{array}$ & 0.18 & 0.09 & 0.06 \\
\hline Humus ( \%) & 0.31 & 0.15 & 0.1 \\
\hline Properties & $\begin{array}{c}1^{\text {st }} \text { layer } \\
(0-0.5 \\
\text { feet })\end{array}$ & $\begin{array}{c}2^{\text {nd }} \text { layer } \\
(0.5-1 \\
\text { feet })\end{array}$ & $\begin{array}{c}3^{\text {rd }} \text { layer } \\
(1-1.5 \\
\text { feet })\end{array}$ \\
\hline Total $\mathrm{N}_{2}(\%)$ & 0.212 & 0.247 & 0.246 \\
\hline $\mathrm{P} \quad(\mathrm{ppm})$ & 3.2 & 4 & 3.6 \\
\hline $\begin{array}{c}\mathrm{K}_{2} \mathrm{O}(\mathrm{mg} / 100 \mathrm{gm} \\
)\end{array}$ & 7.87 & 11.51 & 14.54 \\
\hline
\end{tabular}

Laboratory : Myanma Agriculture Service ( Land Use ) In this table, CEC values of the three layers are not significantly different and the values for exchangeable $\mathrm{Na}$ are nearly the same amount. $\mathrm{EC}_{\mathrm{e}}$ value for the second layer gives the highest one among the tested layers. The salinity profile for the soil sample (initial $\mathrm{EC}_{\mathrm{e}}$ ) is given in Figure 4.1.

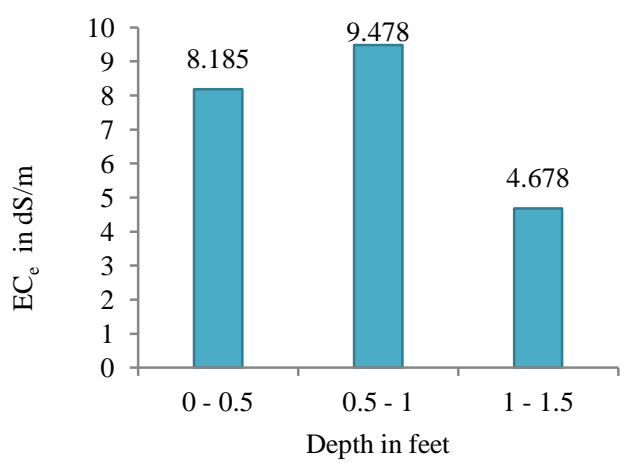

Figure. 4.1. Salinity Profile for Representative Soil Sample Soil $\mathrm{pH}$, although not a salt test, is often tested in a comprehensive soil analysis. It measures the hydrogen ion concentration in soil solution- an important indication of the chemical status of the soil. Since soluble salts affect soil $\mathrm{pH}$ and vice versa, it is often included in evaluations and discussions of soil saltiness. A main implication of changing the soil $\mathrm{pH}$ is plant nutrient availability, which is often a secondary response to microbial activity levels responding to change soil $\mathrm{pH}$.

\subsection{Soil Remediation Studies}

Soil remediation is the essential operation for recovering the spoiled land, to be used for agricultural purpose. There are a number of remediation techniques for salt-contaminated soil.
The concept of soil remediation is to separate the contaminants out of soils and retain or improve soil structure. The most recognized techniques are leaching, ground-water control, draining and chemical application. In practical, leaching and chemical application are the appropriate techniques for saline-sodic and sodic soils.

\subsubsection{Choice of Amendment}

The choice of an amendment at this experiment depends upon its relative effectiveness as judged from improvement of soil properties and crop growth and the relative costs involved. The time required for an amendment to react in the soil and effectively replace adsorbed sodium is also a consideration in the choice of an amendment. Because of its high solubility in water, calcium chloride is the most readily available source of soluble calcium but it has rarely been used for reclamation on an extensive scale because of its high cost. Similarly iron and aluminium sulfates are usually too costly and have not been used for any large-scale improvement of sodic soils in the past, so that these chemicals are not used in this experiment. In addition, cost and effectiveness in remediation processes must be considered together with the available resources, specific factors affecting the remediation environment and the time factor involved in the selected process. As a soil amendment, there are the only demonstrated benefits derived from applying gypsum. The following proven benefits of gypsum used are:

(a) Correction the damaging effects of high soil sodium (Na)

(b) A source of readily plant-available $\mathrm{Ca}$

(c) A source of readily of plant-available $\mathrm{SO}_{4}-\mathrm{S}$

(d) Increase the $\mathrm{pH}$ of highly acid subsoils

(e) Reducing Al toxicity of highly acid subsoils

(f) Possible benefits by lessening the severity of soil surface crusting

(g) Gypsum can reduce ammonia volatilization from urea and UAN fertilizer

Thus, being cheapest and most abundantly available, gypsum which is the most widely used amendment is chosen in this work.

The purity of gypsum was determined in MAS and the obtained values are described as follow;

$\begin{array}{cc}\text { Properties } & \% \\ \text { Moisture } & 8.43 \\ \text { Total Ca } & 19.195 \\ \text { Total S } & 9.042 \\ \text { Purity } & 48.664\end{array}$

\subsubsection{Reclamation of Salt-affected Soils by Gypsum} Gypsum use as an agricultural amendment (in highly weathered soils ) provides the plant nutrients $\mathrm{Ca}^{2+}$ and $\mathrm{SO}_{4}{ }^{2-}$ and improves plant growth through ameliorating deficiencies of these plant nutrients. In alkaline soils, as in this study, if provides $\mathrm{Ca}^{2+}$ without increasing $\mathrm{pH}$ as liming compounds do $\left(\mathrm{CaO}\right.$ and $\left.\mathrm{Ca}(\mathrm{OH})_{2}\right)$. In the remediation process, when the gypsum dissolves, the $\mathrm{Ca}^{2+}$ helps to displace excess sodium $\left(\mathrm{Na}^{+}\right)$from the soil cation exchange complex and clay particles which are formerly dispersed by $\mathrm{Na}^{+}$are then able to aggregate thereby improving soil structure. Well-developed soil structure allows water infiltration and gas exchange which are vital to healthy growth; water-stable aggregates do not 
disperse under wet conditions but maintain their structure and allow water infiltration into and drainage through the soil. Poor infiltration may cause drought stress in crop plants due to lower soil moisture levels, and poor gas exchange under wet conditions deprives plant roots of oxygen needed for root respiration while exposing them to high levels of $\mathrm{CO}_{2}$.

Gypsum replaces sodium ions in the soil with calcium, and as a result, actively removes the sodium and improves soil percolation. This option is applicable only when the $\mathrm{pH}$ of the soil is higher than 8.5 (i.e a sodic soil) as in the case of this work and when simple mechanical breakdown of the compacted clay/silt layer is not effective. Crude gypsum is available in Northern Shan State and its cost is Ks 4000 per ton which is suitable for soil amendment.

The calculated amounts of gypsum requirement for the tested soil are given as follows:

$\begin{array}{cc}\text { Soil Depth (feet) } & \text { Gypsum requirement }(\mathrm{kg} / \mathrm{acre}) \\ 0-0.5 & 1218.62 \\ 0.5-1 & 1044.53 \\ 1-1.5 & 70.445\end{array}$

If only consider for rice cropping system at the soil collected area, total cost of gypsum treated will be about Ks 10000 per acre for 1 feet soil depth. As the roots of the paddy reach about $20 \mathrm{~cm}$ below the surface, the calculated amount of gypsum is sufficient to soil reclamation.

In this study, the chemical application (gypsum) in soil remediation processes primarily aims to adjusting soil $\mathrm{pH}$. Gypsum was used for ion replacement or neutralizing alkali ions in the soils. Gypsum reacts with both $\mathrm{Na}_{2} \mathrm{CO}_{3}$ and the adsorbed sodium which contains in soil sample as follows:

$\mathrm{Na}_{2} \mathrm{CO}_{3}+\mathrm{CaSO}_{4} \leftrightarrow \mathrm{CaCO}_{3}+\mathrm{Na}_{2} \mathrm{SO}_{4(\mathrm{~s})}$

2Na- Micell $\mathrm{CaSO}_{4} \leftrightarrow \mathrm{Ca}-\quad$ Micell ${ }_{2} \mathrm{SO}_{4(\mathrm{~s})}$

Viewing from this reaction, $\mathrm{Na}_{2} \mathrm{SO}_{4}$ are soluble in the soil and these $\mathrm{Na}^{+}$ions can be easily removed by leaching with water. Salt starts to come out from the remedied soil when treated with gypsum after 4 days is shown in Figure. 4.2.

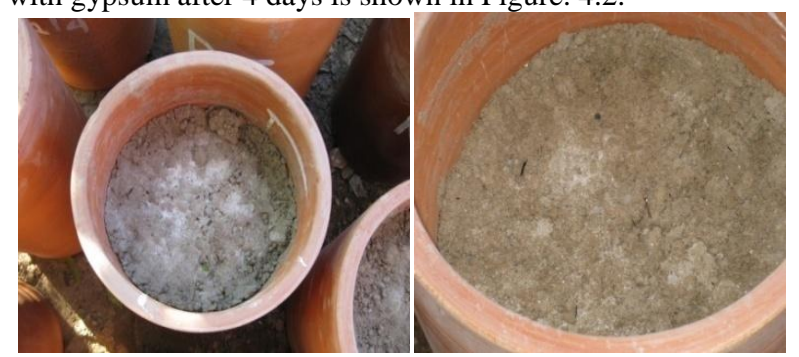

Figure. 4.2. Appearance of Salt Crystal $\left(\mathrm{Na}_{2} \mathrm{SO}_{4}\right)$ from Soil after Gypsum Treatment

The removal of sodium lowers the sodium permeability hazard allowing for soil aggregation and improved drainage. Gypsum does not change $\mathrm{pH}$ nor improve drainage in nonsodic situations. From the research reported studies, gypsum alone does not solve a high $\mathrm{Na}$ problem, so that the adequate irrigation water ( or for enough rainfall) must be applied to leach the displaced $\mathrm{Na}$ out of the root zone. To say a much more in-depth discussion, pure gypsum will not affect the $\mathrm{pH}$ of the top soil when surface applied or incorporated by typical methods.

After the gypsum and leaching treatment, it was found that both the improvement in soil structure and soil permeability but $\mathrm{pH}$ values are still at the alkaline condition $(\sim 9.3)$. Lowering the $\mathrm{pH}$ is a slow process and will take 1-2 years to see a reaction. For more rapid results in lowering $\mathrm{pH}$, sulfur is used.

The $\mathrm{pH}$ of an alkaline soil is lowered by adding sulfur, iron sulphates or aluminium sulphate, although these tend to be expensive and the effects are short term. For this reason, gypsum was used in this study and rice is a suitable crop for the remedied soil $\left(\mathrm{pH} \sim 9.3, \mathrm{EC}_{\mathrm{e}} \sim 2.57\right.$ and $\left.\mathrm{ESP} \sim 14.177\right)$. Alternatively, selecting salt-tolerant crops may be needed in addition to managing soils.

\subsubsection{Reclamation of Salt affected Soil by Leaching}

Leaching is the usual way to reclaim salt-affected soils because plant solute uptake removes insignificant amounts of salt. It can be performed to areas where water for leaching is available. Salt leaching involves the dissolution of soluble salts in the soil, the passage of water through soil profiles, and the removal of salt from the root zone. Thus, soils to be reclaimed must be permeable and have outlets for drainage.

In this experimental study, 16 flower-pots of same size and height $\left(1.5^{\prime} \times 8.5^{\prime}\right)$ were used for the representative soil sample to make gypsum treatment followed by leaching methods. The leaching water of each pot is maintained above the soil surface of $3 \mathrm{~cm}$ during the 4 weeks treatments, whereas, the water soluble salts in the pots are slowly permeable throughout the pots.

In the leaching process, applied water is taken up by the fine roots of plants through the process of osmosis, which involves the movement of water from regions of low salt concentration (such as the soil) to regions of high salt concentration (such as the inside of root cells ). When salt concentrations in the soil are high, the movement of water from the soil to the root is slowed down. When the salt concentrations in the soil are higher than inside the root cells, the soil will draw water from the root, and the plant will wilt and die. This is the basic way in which salinization affects plant production.

The damaging effects of salt on plants are caused not only by osmotic forces, but also by toxic levels of sodium and chloride. Also, the high $\mathrm{pH}$ value (a measure of the acid/alkaline balance) caused by excess sodium may result in micronutrient deficiencies in the plant. Thus, soil leaching is believed to be the only practical way to reduce excessive soluble salts from soils.

The extent of leaching requirement depends largely on initial salt problem, the salt tolerance of the crops, and the depth of the water. To reclaim salt-affected virgin land, the leaching may be conducted for several months or more. As the leaching requirement defined, the fraction of the applied water ( irrigation water) that must be leached through the root zone to control soil salinity at any specified level. For this work, total amount of leaching water ( $\sim$ tap water ) for one pot, ca. 26 liters was used ( always maintain the water layer, $3 \mathrm{~cm}$ above the soil surface ) in the removal ( control ) of salinity. The amount of leaching water was not sufficient to solubilize the applied gypsum, otherwise it can't react completely the soluble salts in the soil. It was found that the salinity was reduced to some extent, knowing from comparison with the measured $\mathrm{pH}, \mathrm{EC}_{\mathrm{e}}$ and $\mathrm{ESP}$ values of initial state and treated state of the soil.

\subsubsection{Analysis of leaching water characteristics}

Tube-well water is used as leaching water in this study. Anions $\left(\mathrm{CO}_{3}{ }^{\circ}, \mathrm{HCO}_{3}{ }^{-}, \mathrm{Cl}^{-}\right.$and $\left.\mathrm{SO}_{4}{ }^{-}\right)$and Cations $\left(\mathrm{Ca}^{++}, \mathrm{Mg}^{++}\right.$, $\mathrm{Na}^{+}$and $\mathrm{K}^{+}$) contains in the leaching water is analyzed and the obtained values are described in Table 4.4. Other characteristics such as $\mathrm{pH}=7.7, \mathrm{EC}=0.244 \mathrm{dS} / \mathrm{m}, \mathrm{SAR}=$ 0.729 are also determined. The total dissolved solids (TDS) 
are lower and the $\mathrm{pH}$ value shows the leaching water is in slightly alkaline condition.

Salinity can only be reduced by leaching with salt-free irrigation water. Because rice has a shallow root system, only the topsoil $(0-20 \mathrm{~cm})$ requires leaching. Cost, availability of suitable water and soil physical and hydraulic characteristics determine the feasibility of leaching. To reduce the level of salinity in affected soils, electrical conductivity in the irrigation ( applied) water should be $<0.5 \mathrm{dS} / \mathrm{m}$. In this work, leaching water of $\mathrm{EC}_{\mathrm{e}} 0.249 \mathrm{dS} / \mathrm{m}$ is applied and the observed value is in the allowable limit.

Clean water is the single indispensable item for desalinization. The amount of water infiltration for leaching, not rainfall, as some of it is lost through surface evaporation and/or surface runoff needed to reach on $\mathrm{EC}_{\mathrm{e}}$ below $4 \mathrm{dS} / \mathrm{m}$ from initial $\mathrm{EC}_{\mathrm{e}}$ value. 'Clean' means water with low $\mathrm{EC}_{\mathrm{e}}$, and with an $\mathrm{EC}_{\mathrm{e}}$ value of less than $0.5 \mathrm{dS} / \mathrm{m}$. Water up to $2 \mathrm{dS} / \mathrm{m}$ is acceptable, but the leaching effect would be lower. Rainwater is ideal since its $\mathrm{EC}_{\mathrm{e}}$ value is almost $0 \mathrm{dS} / \mathrm{m}$. The results of this investigation suggest that if the excess soluble salts are leached down, the properties of saline-alkali soils may change markedly and become similar to those of non-saline-alkali.

Table 4.4. Chemical Analysis of Applied Leaching Water Sample

* Analysed by MAS ( Land Use ), ND = Not Detected

\begin{tabular}{|c|c|}
\hline Constituents & Results* \\
\hline \multicolumn{2}{|c|}{ Anions ( meq/l ) } \\
\hline $\mathrm{CO}_{3}{ }^{*}$ & $\mathrm{ND}$ \\
\hline $\mathrm{HCO}^{-}$ & 1.2 \\
\hline $\mathrm{Cl}^{-}$ & 0.2 \\
\hline $\mathrm{SO}_{4}{ }^{-}$ & $\mathrm{ND}$ \\
\hline \multicolumn{2}{|c|}{ Cations ( meq/l ) } \\
\hline $\mathrm{Ca}^{++}$ & 0.15 \\
\hline $\mathrm{Mg}^{++}$ & 0.1 \\
\hline $\mathrm{Na}^{+}$ & 0.258 \\
\hline $\mathrm{K}^{+}$ & 0.04 \\
\hline $\mathrm{pH}$ & 7.7 \\
\hline $\mathrm{EC}(\mathrm{dS} / \mathrm{m})$ & 0.249 \\
\hline $\mathrm{SAR}$ & 0.729 \\
\hline $\mathrm{TDS}(\mathrm{mg} / \mathrm{L})$ & 156.16 \\
\hline
\end{tabular}

\subsection{Statistical Evaluation with RCBD}

A completely Randomized Design is set up in this experiment in which the treatments are assigned to the experimental units completely at random. This allows every experimental unit to have on equal probability of receiving a treatment. An experiment with 4 treatments $(\mathrm{A}, \mathrm{B}, \mathrm{C}, \mathrm{D})$ and 4 replications of each treatment is done. The flower pots are labeled A, B, C, $\mathrm{D}$ and set up the experimental design as follow:

\begin{tabular}{|c|c|c|c|}
\hline $\mathrm{C}$ & $\mathrm{A}$ & $\mathrm{B}$ & $\mathrm{D}$ \\
\hline $\mathrm{A}$ & $\mathrm{D}$ & $\mathrm{B}$ & $\mathrm{C}$ \\
\hline $\mathrm{D}$ & $\mathrm{B}$ & $\mathrm{C}$ & $\mathrm{A}$ \\
\hline $\mathrm{A}$ & $\mathrm{C}$ & $\mathrm{D}$ & $\mathrm{B}$ \\
\hline
\end{tabular}

where, $\mathrm{A}=$ Soil for $1^{\text {st }}$ layer

$\mathrm{B}=$ Soil for $2^{\text {nd }}$ layer

$\mathrm{C}=$ Soil for mixed layer

$\mathrm{D}=\quad$ Soil for mixed layer (control); no gypsum
The RCBD design is used to study in this experiment to compare the treatments over a wide range of data collection $\left(\mathrm{pH}, \mathrm{EC}_{\mathrm{e}}, \mathrm{ESP}\right.$ values) generalizability, as well as statistical analysis. $\mathrm{T}$ represents for the gypsum treatment in this work and the four treatments $\left(T_{1}, T_{2}, T_{3}, T_{4}\right)$ are the average values for the observed data of Row 1, 2, 3 and 4. This means that $T_{1}$ $=\left(\mathrm{R}_{1} \mathrm{~T}_{1}+\mathrm{R}_{2} \mathrm{~T}_{1}+\mathrm{R}_{3} \mathrm{~T}_{1}+\mathrm{R}_{4} \mathrm{~T}_{1}\right) / 4$ and so on. The determined values of $\mathrm{pH}, \mathrm{EC}_{\mathrm{e}}$ and $\mathrm{ESP}$ at the time intervals of the treatment are represented in Figures 4.3, 4.4 and 4.5.

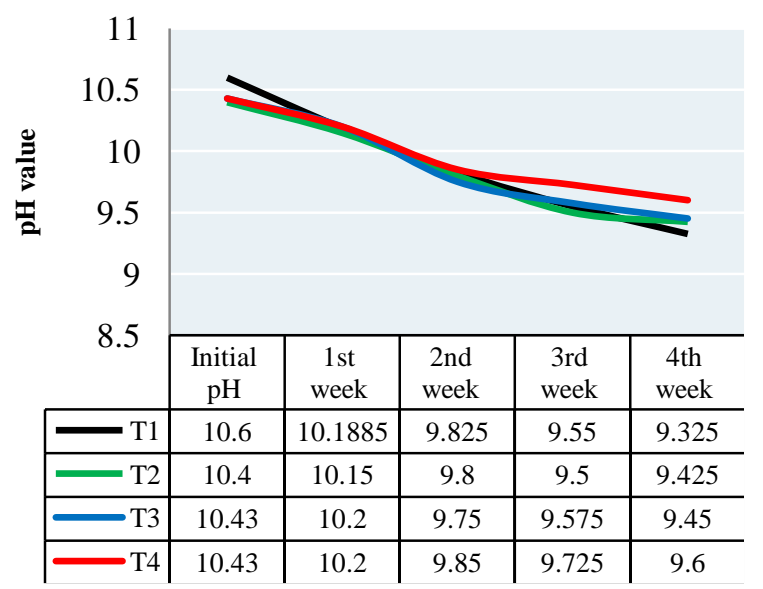

Figure. 4.3. pH Values of Gypsum Treated Soil for 4 Weeks Interval

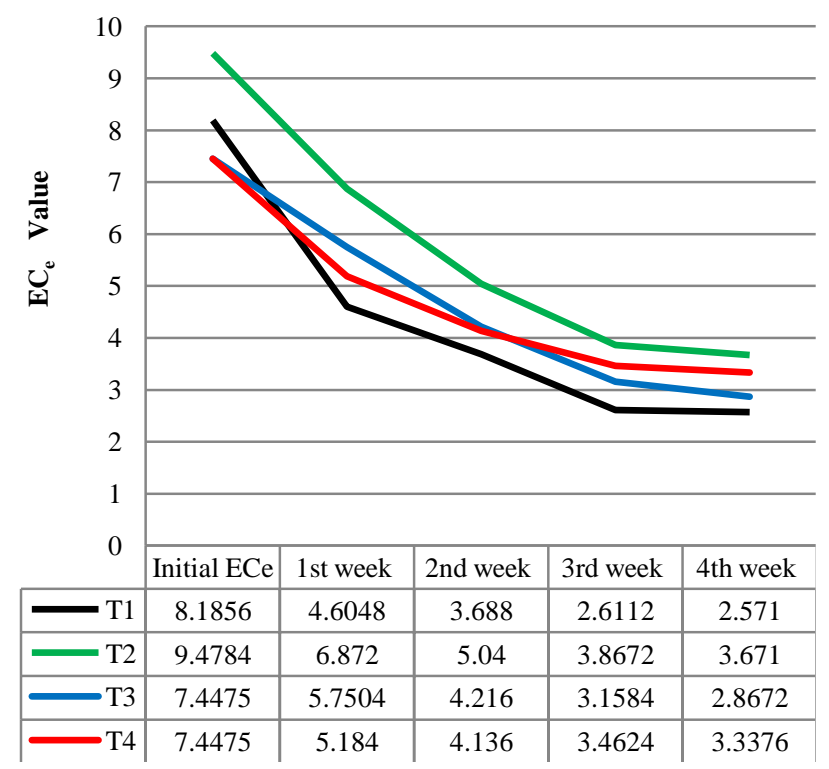

Figure. 4.4. $\mathrm{EC}_{\mathrm{e}}$ Values of Gypsum Treated Soil for 4 Weeks Intervals

$\mathrm{EC}_{\mathrm{e}}$ values express for salinity are also measured in this study and the average values of 16 flower pots in RCBD design are represented in Fig 4.4. For the $1^{\text {st }}$ and $2^{\text {nd }}$ soil layer (i.e $T_{1}, T_{2}$ which represented as $\mathrm{A}$ and $\mathrm{B}$ pot ), $\mathrm{EC}_{\mathrm{e}}$ values decrease from 8.185 to 2.571 and 9.478 to 3.671 , respectively. For the pot $\mathrm{C}$ and $\mathrm{D}$ (control) the initial $\mathrm{EC}_{\mathrm{e}}$ values are the same and after $4^{\text {th }}$ week, these values are reduced to 2.867 and 3.337 . 


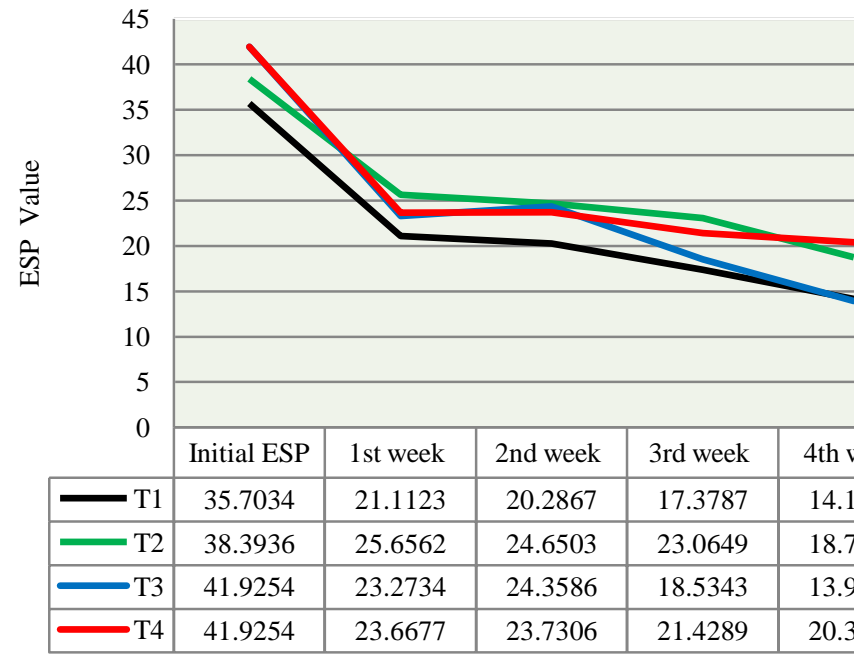

Figure. 4.5. ESP Values of Gypsum Treated Soil for 4 Weeks Interval

Viewing the measured ESP values of gypsum treated soil in Fig. 4.5, for Pot A and B, it was occurred that ESP values were significantly decreased to some extent. In the case of Pot $\mathrm{C}$ and D, the ESP values are also decreased, but not appreciably different value as found in Pot A and B. The presence of excessive amounts of exchangeable sodium reverses the process of aggregation and causes soil aggregates to disperse into their constituent individual soil particles. This is best achieved by the application of gypsum because the calcium $\left(\mathrm{Ca}^{2+}\right)$ in gypsum displaces sodium $\left(\mathrm{Na}^{+}\right)$on the exchange site. In turn, the sodium reacts with sulfate $\left(\mathrm{SO}_{4}{ }^{2-}\right)$ from sodium sulfate $\left(\mathrm{Na}_{2} \mathrm{SO}_{4}\right)$, which is a highly water soluble material ( leachable) that is leached from the soil.

It can be clearly seen that leaching treatment is efficient and effective way in salt removal when studies from comparing the ESP values of the Pot D with Pot A, B, C. Owing to the observed ESP values in $4^{\text {th }}$ week of Pot A, B, C and D are $14.177,18.735,13.936$ and 20.399 which are not significantly different.

Table 4.5. Reduction Efficiency (\%) of $\mathrm{pH}, \mathrm{EC}_{\mathrm{e}}$ and $\mathrm{ESP}$ after 4 Week Interval

\begin{tabular}{|c|c|c|c|}
\hline \multirow{2}{*}{ Pot } & \multicolumn{3}{|c|}{ \% reduction efficiency } \\
\cline { 2 - 4 } & $\mathrm{pH}$ & $\mathrm{EC}_{\mathrm{e}}$ & ESP \\
\hline $\mathrm{A}$ & 12.0283 & 68.5911 & 60.2903 \\
\hline $\mathrm{B}$ & 9.375 & 61.2698 & 51.2005 \\
\hline $\mathrm{C}$ & 9.3959 & 61.5011 & 66.7598 \\
\hline $\mathrm{D}$ & 7.9578 & 55.1849 & 51.3438 \\
\hline
\end{tabular}

The reduction efficiency of the soil salinity $\left(\mathrm{pH}, \mathrm{EC}_{\mathrm{e}}, \mathrm{ESP}\right.$ ) are studied and the calculated value are described in Table 4.5. As sodium toxicity problem is the most important in soil reclamation, the decreasing amount of ESP (i.e the removal of $\mathrm{Na}^{+}$ion) is studied among pot $\mathrm{A}, \mathrm{B}, \mathrm{C}$ and $\mathrm{D}$. The reduction in ESP of surface level (i.e first layer) in Pot A shows $60.2903 \%$ when compared with Pot $\mathrm{C}$ has a higher value, $66.7958 \%$. In Pot $\mathrm{C}$, there are mixed layer (i.e contain the first, second and third layer soils). Even though the reduction efficiency is higher in Pot $\mathrm{C}$, it is not required for rice crop and ploughing depth (up to 1 feet) in the paddy field is adequate. The reduction of $\mathrm{EC}_{\mathrm{e}}$ for the first layer soil is 68.5911 which can be explained more clearly. This means the salinity is reduced to $\mathrm{EC}_{\mathrm{e}}$ value of $2.571 \mathrm{dS} / \mathrm{m}$ after treatment of 4 week interval which is less than $4 \mathrm{dS} / \mathrm{m}$.

Observing the $\mathrm{pH}$ values of Pot $\mathrm{A}, \mathrm{B}, \mathrm{C}$ and $\mathrm{D}$, the reduction efficiency of the top soil layer (Pot A) is the highest $(12.0283 \%)$ and decrease to 9.325 after the treatment.

Thus, it can be suggested that the soil layer depth (up to 1 feet) is adequate, and the soil from three layers can thoroughly mix after the disking in practical.

\subsection{Experimental Test Studies on Rice Plantation}

According to the classification of crop tolerance to salinity, the rice crop is within the sensitive division from $0 \mathrm{dSm}^{-1}$ to 8 $\mathrm{dSm}^{-1}$ (i.e medium salt tolerance). There are two essential parameters sufficient for expressing salt tolerance. Threshold means the maximum allowable salinity without yield reduction and slope means the percent of yield reduction per unit increasing in salinity beyond the threshold. The threshold and slope of rice (Oryza sativa) are $3.0 \mathrm{dSm}^{-1}$ and $12 \%$ per $\mathrm{dSm}^{-1}$ of saturated soil extract $\left(\mathrm{EC}_{\mathrm{e}}\right)$ respectively.

When sufficient fresh water is available during the monsoon season, the salts are dissolved and diluted in the surface soil layers and washed out from plant's shallow root zone, thus the plant growth is not inhibited. But investigations showed that rice is most susceptible to saline soils at the stage of germination, shoots and flowering. In the present study, the rice plant does not germinate during the observation period of 8 days on untreated (original soil) although they can grow well at Pot A, B, C and D after treatment.

It was found that salt concentration increase has osmostic and toxic influence. Osmotic influence of salts mainly causes delay of water penetration into cells and dehydration of protoplasm. Toxic influence of salts is especially strong in case of excess accumulation of chloride ions in shoots. When rice is grown on saline soils at emergence plant density is high, but at the stage of $2-3$ leaf it decrease due to dying away of shoots. That is why at germination stage it is important not to have high salinity level of subsurface soil layer and irrigation (leaching) water. Thus, soil salinization suppresses rice growth and yield.

Summer rice is cultivated using the irrigation water from the rivers and streams. In delta region, sea water penetrates deeper in rivers and streams entering the sea so that the problem of salinity of irrigation water occurs. The quality of irrigation water provided by rivers and streams is also variable and salt contents tend to be higher in summer season. Protection against these types of unpredictable salinity can be achieved by growing salt tolerant varieties, especially for summer rice. In this study, a local rice variety Ayershwewar is used to study for the response to salinity at germination and young seedling stages in Figure 3.8. Due to the results of this experimental study, it can be said that rice can grow well on the soil after amendment. It is not always clear, however, whether varietal difference reflect differences in salt tolerance or differences in adaptation to climatic or nutritional conditions under while the tests are conducted.

From FAO field guide, for rice cropping and $\mathrm{EC}_{\mathrm{e}}$ value of less than $4 \mathrm{dS} / \mathrm{m}$ at the time of transplanting is best for root formation as an ideal level which meets with all pots in this experiment. If this is achieved and if subsequent water management or may be rainfall is appropriate, there will be no salinity problem throughout the cropping system. 


\section{CONCLUSION AND RECOMMENDATIONS}

\subsection{Conclusion}

Excess soil salinity causes poor and spotty stands of crops, uneven and stunted growth and poor yields, the extent depending on the degree of salinity. The primary effect of excess salinity is that renders less water available to plants although some is still present in the root zone. This is because the osmotic pressure of the soil solution, excessive concentration and absorption of individual ions may prove toxic to the plants and/or may retard the absorption of other essential plant nutrients.

The problem soil area of Mandalay Division (Upper Myanmar) which is not explored before, recognized by Agriculture Department, was selected to study in this work. The feasibility of using local gypsum as ion providing agents for remediation of salt-contaminated soil has been examined in this study. Experimental studies from this work indicated that the effective remediation technique for this particular type of salt contaminated soils involves a series of treatments. Practically in the soil collected area, first, the surface of the contaminated soil (> 20 cm deep) is required to be ploughed and thoroughly mixed so as to provide some degree of liquid irrigation channel. Second, local gypsum powder is applied to the soils with a rate of (7.7434 tonne/ha) so as to neutralize the soil condition. Third, the soils are leached using water at a rate of $\left(13500 \mathrm{~m}^{3} / \mathrm{ha}\right)$ to wash away the undesirable compounds.

Based on the above experiments, the following findings are observed as:

(a) From the classification and characterization of saltaffected soil, it is found that the soil sample is salinealkaline type.

(b) The initial ( $\mathrm{pH}, \mathrm{EC}_{\mathrm{e}}$, ESP ) values are determined and the observed values for the top layer $(0.5 \mathrm{ft})$ are 10.6 , 8.1856 and 35.7034 , respectively.

(c) Local gypsum treatment followed by leaching is carried out as a soil remediation technique in this work.

(d) The tested soil salinity is reduced to some extent, from the studies of $\mathrm{pH}, \mathrm{EC}_{\mathrm{e}}, \mathrm{ESP}$ measurement, after the observed period.

(e) Randomized Complete Block Design (RCBD) is used to investigate data analysis by 2 way ANOVA for the statistical evaluation.

With this technique, the contaminated soils are found to be well conditioned, i.e. their electrical conductivity is reduced from 8.185 to $2.571 \mathrm{dS} / \mathrm{m}$ (slightly saline), ESP is reduced from 30.703 to $14.177 \mathrm{ppt}$ (moderately sodic), and $\mathrm{pH}$ is decreased from 10.6 to 9.3 for the first soil layer in the lab scale experiments. It is assumed (apparent) that time required for the removal of $\mathrm{Na}^{+}$ion is not sufficient to solubilize out in the leaching water.

For rice crops, soil salinity beyond ECe $\sim 4 \mathrm{dS} / \mathrm{m}$ is considered moderate salinity while more than $8 \mathrm{dS} / \mathrm{m}$ becomes high. Similarly pH $8.8-9.2$ is considered as nonstress while 9.3 9.7 as moderate stress and equal or greater than 9.8 as higher stress. The above reason shows that the treated soil in this work is acceptable for rice planting.

Viewing from these results, it can be concluded that this approach is technically feasible to be extended to the real application for salt contamination in saline-alkaline soil in tropical areas.

\subsection{Recommendations}

Further works of this study are suggested as follow;

(a) Soil sampling techniques is quite important in soil reclamation and soil samples should be carried out with the help of geologist and agriculturist.

(b) In the studies of soil management, sample collection should be done for the whole growing cycle at field condition under wet and dry season and examined the representative profile for overall purpose.

(c) The field before reclamation should be deep ploughed and leveled in a manner to allow the equal spread of irrigation water.

(d) The availability of water is another factor for amendment reaction in those problem soils.

(e) The use of local gypsum (purity $48.664 \%$ ) is effective in amelioration of saline-sodic soils, but should be passed through $2 \mathrm{~mm}$ sieve and having a range of particle size distribution helped in maintaining permeability at higher level and for a longer period.

(f) Continuous flooding should also be considered in those areas where gypsum is not available.

(g) Adequate availability of good-quality water must be required for leaching during the reclamation process.

(h) Also, the amount of leaching water required is the main critical factor to solubilize the gypsum because of its limited (low) solubility.

(i) Leaching should preferably be done when the soil moisture content is low and the ground water table is deep.

(j) It is important to note that there must be adequate drainage in the soil to leach the salts out of the profile, otherwise salts may build up lower in the soil profile and continue to cause problems.

Soluble salts comes out from leaching process is mostly $\mathrm{Na}_{2} \mathrm{SO}_{4}$ as a byproduct and it can utilized in many industries. Thus, it should be collected as a pool to pass through a drainage system in practice. The essential soil conditions after leaching must be the following criteria:

(a) Soil salinity should be less than $1.0 \mathrm{ppt}$.

(b) Soil conductivity should be less than $2 \mathrm{dS} / \mathrm{m}$.

(c) Soil $\mathrm{pH}$ should be in the range of 6.5 to 7.5 .

(d) There is a reduction of toxic ions $\left(\sim \mathrm{Al}, \mathrm{Na}^{+}, \mathrm{Cl}^{-}\right)$.

(e) Soil texture should be ready for agricultural uses.

(f) These soil conditions should remain steady state for a reasonably long period.

Land rehabilitation efforts should be made other conventiona methods such as appropriate drainage, deep rooting crops, the physical removal of salts and flushing might be introduced when and where appropriate.

A final approach should be taken, if possible, to predict and attempt to prevent salinization in susceptible areas through a thorough study of all environmental factors, such as the geology, climate and hydrology of the area.

\section{ACKNOWLEDGMENTS}

The author is also grateful to her supervisor Daw Si Si Win, Visiting Lecturer, Department of Chemical Engineering, Yangon Technological University, for giving invaluable advice and support.

The most grateful acknowledgement is extended to Ei Mon Khin for her idea approaching to the practical and theoretical methods useful discussions, hardwork and invaluable suggestions for this journal. 
The author is greatly indebted to all of her teachers from Department of Chemical Engineering who helped with their knowledge and invaluable advices.

The author is also grateful to Daw Thwe Thwe Oo, Associate Professor and Head of Department of English, Technological University (Hmawbi), and all the teachers of English Department, Technological University (Thanlyin), for editing from the language point of view. The author would like to express her deepest gratitude to her beloved parents for their moral support, guidance and encouragement during this long period and throughout her entire life.

\section{REFERENCES}

[1] FAO. 2000. Land Resource Potential and Constraints at Regional and Country Levels, World Soil Resources Reports 90. Rome, Italy: FAO, Land and Water Development Division.

[2] Goodie, A.S. 1990. Soil Salinity Causes and Controls. Techniques for Desert Reclamation. England, John Wiley and Sons, Ltd; pp 110-111.

[3] Anon. 2009. Soil Salinity Control, Wikipedia.

[4] Rachel, B. 2008. Guidelines for the Application of Recycled Gypsum as a Soil Amendment in Western and Central Montana Agricultural Soils, Missoula, MT.

[5] Abu-Zreig, M.M., Abe, Y., and Isoda, H. 2006. "Study of Salt Removal with Evaporation Drainage Method", Canadian Biosystems Engineering.

[6] Anon. 2010. Soil Salinity, <http://www.Wikipedia.com>

[7] Dobermann, A and Fairhurst, T. 2000. Rice: Nutrient Disorders \& Nutrient Management, Handbook series. Potash \& Phosphate Institute (PPI), Potash \& Phosphate Institute of Canada (PPIC) and International Rice Research Institute. $191 \mathrm{p}$.

[8] Abrol, I.P. 1988. Salt-Affected Soil and their Management, Rome.

[9] Blaylock, A.D. 1994. Soil Salinity. Salt Tolerance and Growth Potential of Horticultural and Landscape Plants.

[10] Win Thein, Mg 2006. Myanma Salt and Salt Products, Ministry of Mines.

[11] Irrigated Crop Management Service ( ICMS ). August 2007. Monitoring Soil Salinity Irrigated Horticulture, South Australia.

[12] Ayers, R.S. and Westcot, D.W. 1976. Water Quality for Agriculture, Irrigation and Drainage Paper 29, FAO, Rome.

[13] Cardon, G.E., Davis, J.G., Bauder, T.A. and Waskom, R.M. 5/2007. Managing Saline Soils.

[14] Anon. 2010. Alkali Soils, <http://www.Wikipedia.com>
[15] Ayers, R.S. and Westcot D.W. 1985. FAO Irrigation and Drainage Paper, Water Quality for Agriculture, Rome.

[16] EN Omami. 2005. Response of Amaranth to Salinity Stress.

[17] Anon. 2001.Agdex 518-17.

[18] Edward Winston etal. 2005, Arabica Coffee Manual for Myanmar.

[19] Barker, A.V., Pilbeam D. J. 2010. Plant Nutrition, <http://www.Wikipedia.>

[20] Roy, R.N., Finck, A., Blair, G.J., Tandon, H.L.S 2006. Plant Nutrition for Food Security, FAO, Rome.

[21] Seelig, B.D. May 2000, Salinity and Sodicity in North Dakota Soils .

[22] Wittaya Thammarith, DEC, 2001, Remediation of Salt-Contaminated Soil from an Abandoned Shrimp Farm, Regina, Saskatchewan.

[23] Deena Bahner, Student On-Line Journal, Vol.5, No.3, Fall 1999, Department of Horticultural Science, University of Minnesota, Reclamation of Salinized Soils In Arid Regions, St. Paul, MN.

[24] Oad, F.C., Samo, M.A., Soomro, A., Oad, D.L., Oad, N.L., and Siyal, A.G. Pakistan Journal of Applied Science, 2002, Amelioration of Salt Affected Soils .

[25] Anon. 2010. Soil Salinity Control, <http://www.Wikipedia.com>

[26] Spectrum Analytic. 2007. Gypsum, Washington Court House.

[27] Richards, L.A. 1954. Diagnosis and Improvement of Saline and Alkali Soils, Washington 25,D.C.

[28] Anon. 2010. Soil conditioner, <http://www.Wikipedia.com>

[29] Arnold Finck and Kiel. 1976. Pflanzenernährung in Stichworten.

[30] Paul Vossen, University of California, Cooperative Extension,2604 Ventura Ave, Santa Rosa, CA 95403.

[31] Anon. 2004. University of Minnesota Extension Service, BU-01731.

[32] Rhoades, J. D. etal. 1999. Soil Salinity Assessment, Rome.

[33] FAO Field Guide, 20 Things to know about the Impact of Salt Water on Agricultural Land in Aceh Province, March 2005.

[34] Anon. 2009. Monitoring Soil Salinity for Irrigated Horticulture ( Fact sheets ), South Australia.

[35] Turner, R.C. etal. 2010. Cation Exchange Capacity, <http://www.Wikipedia.>

[36] UNSW. 2007. Soil Properties, Australia.

[37] Edaphos. 1999. Dynamics of a Natural Soil System, Las Vegas, Nevada U.S.A. 